\title{
Fornuftens gang igennem filosofihistorien - pragmatisk set
}

Cheryl $M$ is ak:

The American Pragmatists (The Oxford History of Philosopby),

Oxford University Press, 2013 , 286 sider, 45 USD.

Efter tidligere at have udgivet bl.a. Gary Cuttings glimrende Thinking the Impossible: French Philosophy since 1960 i den nye filosofihistoriske serie The Oxford History of Philosophy har Oxford University Press nu følt, at tiden er kommet til en filosofihistorisk behandling af den amerikanske pragmatisme og personen de har udset sig til at skrive denne historie er Cheryl Misak, professor i filosofi ved University of Toronto, Canada, og stor kender (og fan) af Charles Peirce's pragmatiske filosofi. Denne inspiration præger da også tydeligt bogen, som overordnet set er et revisionistisk forsøg på at omskrive pragmatismens historie sådan så Peirce - som aldrig fik en fast stiling, havde et kaotisk liv og offentliggjorde meget lidt fremstår som den store pragmatiker der stadig kan og bør inspirere filosoffer i dag.

Den store modstander $\mathrm{i}$ denne historie er umiddelbart Louis Menand's fortælling om pragmatismens historie i hans prisbelønnede The Metaphysical Club, hvor pragmatismens opkomst kædes sammen med den amerikanske borgerkrig lige som dens nedgang efter 2. verdenskrig forbindes med den kolde krig og McCarthyismen. Da Misak anser Menand for at være direkte inspireret af Richard Rorty og hans forståelse af pragmatismens historie, bliver det dog Rorty (og indirekte hans pragmatiske inspirationskilder William James og John Dewey), som er hendes egentlige modstander og den hun ønsker "at fravriste betegnelsen pragmatisme" (s. 237). Som hun ser det er det nemlig Rorty, som er ansvarlig for det herskende "eclipse" (formørkelses) syn på pragmatismens historie. Ifølge dette syn opstod pragmatismen som en særlig amerikansk form for filosofi omkring den amerikanske borgerkrig i diskussi- 
onsklubben "the metaphysical club" på Harvard (hvor bl.a. Peirce og James var medlemmer), kulminerede med Dewey's status som Den Amerikanske Filosof i mellemkrigstiden, men blev så formørket op til og efter Dewey's død i 1953 på grund af de tyske logiske positivisters flugt fra Hitler og efterfølgende overtagelse af de amerikanske filosofiafdelinger med deres analytiske filosofi, hvis 'videnskabeligt' neutrale selvbillede passede bedre til det politiske klima under den kolde krig. Først med Rorty's relancering af en James- og Dewey-inspireret pragmatisme i begyndelsen af 1980erne blev det endeligt muligt for pragmatismens sol at træde ud af formørkelsen og oplyse det golde analytisk-filosofiske landskab.

Misak's greb overfor denne fortælling består som allerede nævnt i en fremhævning af en anden linie i pragmatismen hvor Peirce står helt centralt, men også sammen med mindre kendte folk som bl.a. Chauncey Wright og C.I. Lewis. Dette greb tillader hende så at se en pragmatisk linie igennem hele den moderne amerikanske filosofihistorie fra de oprindelige pragmatister, over de logiske positivister og disses mest fremtrædende elever (Quine, Sellars, Goodman) op til dominerende nutidige filosoffer som Putnam og Davidson. Bogens struktur følger også denne grundfortælling, så dens første del om pragmatismens grundlæggere først meget kort introducerer det intellektuelle landskab pragmatismen opstod i, før centrale figurer som Wright, Peirce og James behandles i selvstændige kapitler, mens mindre figurer som Oliver Wendell Holmes, Josiah Royce of F.C.S Schiller tildeles et fælles kapitel. I den anden del, med titlen "mellemperioden", behandles først den tidligere pragmatismes receptionshistorie, hvorefter Dewey's filosofi gennemgås grundigt - og kritisk - i bogens længste kapitel, inden tænkere som George Herbert Mead og George Santayana kort behandles som "medpassagerer". I den afsluttende tredje del føres historien så op til i dag, ved først at behandle den logiske positivismes forhold til pragmatismen i et kapitel, hvorefter C.I. Lewis, Quine, Rorty og Putnam alle tildeles et kapitel (Morton White, Nelson Goodman og Wilfrid Sellars behandles også kort undervejs), inden det konkluderes at pragmatismen, i en Peirceansk udgave, lever og har det vel som en del af mainstream amerikansk filosofi og altid har gjort det, selv om folk som Rorty har været så forblindede og formørkede at de ikke kunne se det.

På trods af at Misaks historie rummer mange interessante cita- 
ter, tanker og anekdoter (hvem kan fx ikke underholdes af Peirce's "when I was a babe in philosophy my bottle was filled from the udders of Kant" - selv om et sådan erotisk forhold til Kant også må siges at være ret skræmmende...), så er der dog også store metodiske og substantielle mangler ved den. Der er således intet som tyder på at hun har gjort sig store (eller små) overvejelser over hvad det vil sige at skrive intellektuel historie - og det kan ses. Det begreb om pragmatismen som strukturerer hele fortællingen behandles således kun yderst kortfattet med vage henvisninger til begrebers forbindelse til praksis og spørgsmålet er hvor frugtbart det egentligt er at skrive historie ud fra dette begreb, som allerede var ekstremt omstridt i samtiden (Peirce, som fandt på det, ville ikke kendes ved det og Dewey var meget varsom med at bruge det). Men det gør Misak sig ingen overvejelser om. For at fortælle sin historie må hun desuden også opløse distinktionen mellem analytisk og kontinental filosofi. Det kan for så vidt være rimeligt nok, men når hun så alligevel vil karakterisere den herskende amerikanske måde at bedrive filosofi på som en særlig streng ("rigorous") måde at argumentere på, kommer hun uundgåeligt i problemer. Det ses tydeligt i kapitlet om Dewey (hvis filosofi denne anmelder kender til) som er præget af en ekstremt løs og usammenhængende argumentation - for at sige det mildt. Central ideer kaldes her "bizarre", "mudrede", "uhjælpsomme", "metafysisk sammenbryg" osv., uden at forfatteren synes at overveje om det måske kunne tænkes at det er den rigide begrænsning som hun sætter så højt i hendes egen måde at tænke på, som gør at ideerne fremstår på denne måde (her kunne hun passende have læst Cuttings bog i samme serie om fransk filosofis forsøg på at tænke "det umulige"). Nøgternt filosofihistorisk synes hun kun at kunne fortælle sin historie ved at skære de Hegelianske elementer i pragmatismens historie bort for at fremhæve de Kantianske som passer meget bedre med det som kaldes analytisk filosofi. Og det er en skam, for hun kunne nok godt lære lidt af Hegels omgang med filosofihistorien, når hun først afviser Menands og Rortys forsøg på at relatere pragmatismens historie til de sociale forhold ved at sige at den Peirceanske pragmatismes dominans "har alt at gøre med de filosofiske fortjenester og problemer forbundet med forskellige versioner af pragmatismen" (s. 252), for derefter, opmuntret, at konkludere at den 'strenge' analytiske måde at tænke 
på i amerikansk filosofi, som ligger så godt i forlængelse af Peirce, "nu måske er ved at vise sig at være udødelig [sic!] som filosofiens dominerende metodologi" (s.156). Hvis der nogensinde har været et eklant eksempel på filosofihistorie som fornuftens gang igennem historien, er det vist her. Ironisk nok er den grundlæggende motivation bag Misak’s egen Peirceanske position (og dermed også bag hendes fortælling om pragmatismens historie) faktisk et ønske om at kunne argumentere imod et magt-er-ret perspektiv, men hun synes helt blind for at hendes egen historie selv fremtræder som et relativt usofistikeret forsøg på at få den herskende form for pragmatisme til at fremstå som den rette. Dette vil uden tvivl medvirke til at en lang række filosoffer vil opleve hendes bog som en behagelig forsikring og påmindelse om at de er på rette vej. Men kampen om begrebet pragmatisme vil utvivlsomt også fortsætte, som en af mange arenaer for filosofisk strid, og det store spørgsmål er måske om det overhovedet er et begreb, som det er værd at kæmpe for.

Martin Ejsing Christensen

\section{Haugelands Heidegger}

Jobn Haugeland (redigeret af Joseph Rouse): Dasein Disclosed: John Haugeland's Heidegger, Harvard University Press, 2013, 336 sider, 49,95 USD.

John Haugeland (1943-2010) er herhjemme nok primært kendt for at være en betydelig stemme i kunstig intelligens forskningen op gennem 80'erne og 90'erne (Mind Design (1981); Artificial Intelligence: The Very Idea (1985); Mind Design II: Philosophy, Psychology, Artificial Intelligence. Second Edition (1997) ). Andre har måske stiftet bekendtskab med visse af hans analytisk-filosofiske artikler, hvoraf mange er samlet i bogen Having Thought, fra 1998. Af fremragende artikler heri kan nævnes, The intentionality all-stars, hvori Haugeland beskriver forskellige intentionalitets-teorier som de forskellige positioner i et spil baseball, og Represenational Genera, som Daniel Dennett i sin anmeldelse af bogen mener bør læses, hvad enten man er enig 